\title{
The Escherichia coli ser $A$-linked capsule locus and its flanking sequences are polymorphic, genetic evidence for the existence of more than two groups of capsule gene clusters
}

\author{
C. Rachel Drake, $†$ Graham J. Boulnois $\ddagger$ and Ian S. Roberts* \\ Department of Microbiology, University of Leicester, PO Box 138, Medical Sciences Building, University Road, \\ Leicester LE1 9HN, UK
}

(Received 8 February 1993; revised 1 April 1993; accepted 5 April 1993)

\begin{abstract}
Two families of Escherichia coli capsules, termed groups I and II, have been defined previously on the basis of a number of biochemical and genetic criteria. Recently, a third group of capsules, termed I/II has been suggested on the basis of chemical structure and mode of expression. In this paper, we show that group I capsule-producing strains lack the ser $A$-linked group II capsule genes. In addition, group I/II capsule-producing strains lack the group II capsule genes despite the former genes also mapping near to $\operatorname{ser} A$. Therefore, the genetic data presented in this paper support the existence of three groups of capsule gene clusters, two of which are linked to $\operatorname{ser} A$. Sequences flanking the $\mathrm{K} 4$ capsule genes were found in the chromosome of all $E$. coli strains examined and were sometimes present in multiple copies at different loci, indicating that this chromosomal region is highly polymorphic.
\end{abstract}

\section{Introduction}

The enormous diversity of $E$. coli capsular polysaccharide ( $\mathrm{K}$ antigen) is striking with over 70 chemically different structural types known (Ørskov et al., 1977). On the basis of chemical structure, size, mode of expression and chromosomal location of genetic determinants the capsular polysaccharides can be divided into two broad groups, I and II (Jann \& Jann, 1987). A given isolate produces a single $\mathrm{K}$ antigen and co-expression or switching of capsule types either within or between groups has not been observed (Jann, 1985).

The expression of group I capsular polysaccharides is restricted to $\mathrm{O} 8$ and $\mathrm{O} 9$ and occasionally $\mathrm{O} 20$ and $\mathrm{O} 101$ serotypes (Jann \& Jann, 1990). They have a low charge density and are expressed at all growth temperatures (Jann \& Jann, 1990). Some group I polysaccharides are anchored in the outer membrane by linkage to core-lipid $A$ and can be thought of as extended lipopolysaccharide

\footnotetext{
*Author for correspondence. Tel. (0533) 522956; fax (0533) 525030 .

†Present address: Department of Physiology and Environmental Science, Nottingham University, Sutton Bonington Campus, Loughborough, Leicestershire, LE12 5RD, UK.
}

$\ddagger$ Present address: ICI Pharmaceuticals, Mereside, Macclesfield, Cheshire, SK 10 4TG, UK.

Abbreviations: KDO, 2-keto-3-deoxy-manno-octulosonic acid; CKS, CMP-KDO synthetase.
(LPS) (Jann \& Jann, 1987, 1990; Jann et al., 1992). Genetic determinants for group I capsule production map near the his and $r f b$ (O antigen synthesis) loci (Ørskov et al., 1977) but have not been analysed in detail. Studies using the K27 antigen indicate that a second trplinked locus is necessary for surface expression of a complete capsule, although this is not the case for the K30 antigen (Schmidt et al., 1977; Laasko et al., 1988).

The group II capsular polysaccharides have a higher charge density than those of group I and are not expressed at low growth temperatures $\left(17-20^{\circ} \mathrm{C}\right)$. Group II capsules are co-expressed with a variety of $\mathrm{O}$ antigens (excluding the four above) (Jann \& Jann, 1987). In all group II capsules so far analysed, the reducing end of the polysaccharide is substituted with phosphatidic acid and this substitution may act as the membrane anchor (Schmidt \& Jann, 1982; Jann \& Jann, 1990). Unlike group I, group II capsule-producing strains have a high CMP-KDO (2-keto-3-deoxy-manno-octulosonic acid) synthetase activity (CKS) at the capsule permissive temperature (Finke et al., 1989, 1990). Genetic determinants for the expression of some group II capsules have been mapped at 64 minutes near ser $A$ on the $E$. coli chromosome (Ørskov et al., 1976; Vimr, 1991) and have been termed kps (Silver et al., 1984; Vimr et al., 1989), formerly kpsA (Ørskov \& Nyman, 1974). Gene clusters encoding several chemically different group II capsular polysaccharides have been cloned and shown to have a common segmental organization (Roberts et al., 
Table 1. Bacterial strains and plasmids

\begin{tabular}{|c|c|c|}
\hline Strain/plasmid & Characteristics & Source/reference* \\
\hline LE392 & $\begin{array}{l}\mathrm{F}^{-} h s d R 514\left(r_{\mathrm{K}}^{-} m_{\mathrm{K}}^{+}\right) \text {supE44 supF58 lacY1 } \\
\text { galK2 galT22 metB1 trpR55 }\end{array}$ & Echarti et al. (1983) \\
\hline 512 & $\mathrm{O} 1: \mathrm{K} 1: \mathrm{H} 7$ & G. J. Boulnois ${ }^{a}$ \\
\hline 20022 & $\mathrm{O} 6: \mathrm{K} 2: \mathrm{H} 1$ & \\
\hline 20242 & $\mathrm{O} 4: \mathrm{K} 3: \mathrm{H} 4$ & \\
\hline $\mathrm{U} 1-41$ & $\mathrm{O} 5: \mathrm{K} 4: \mathrm{H} 4$ & \\
\hline B18337-41 & $\mathrm{O} 10: \mathrm{K} 5: \mathrm{H} 4$ & \\
\hline 2667 & $\mathrm{O} 9: \mathrm{K} 9: \mathrm{H} 12$ & K. Jann ${ }^{b}$ \\
\hline 21454 & O11:K10: $\mathrm{H}^{-}$ & \\
\hline 21455 & O13:K11:H11 & \\
\hline 21456 & $\mathrm{O} 25: \mathrm{K} 19: \mathrm{H} 12$ & \\
\hline 2904 & $\mathrm{O} 9: \mathrm{K} 29: \mathrm{H}^{-}$ & \\
\hline B22 & $\mathrm{O9:K30:H12}$ & C. Whitfield ${ }^{c}$ \\
\hline $\mathrm{A} 12 \mathrm{~b}$ & O6:K54:H10 & F. Ørskov ${ }^{d}$ \\
\hline pACYC184 & $\mathrm{Cm}^{\mathrm{r}} \mathrm{Tc}^{\mathrm{r}}$ & Chang \& Cohen (1978) \\
\hline pGB 110 & Carries the $\mathrm{K} 5$ antigen gene cluster & Roberts et al. (1986) \\
\hline pKT172 & Carries the $\mathbf{K} 1$ antigen gene cluster & Echarti et al. (1983) \\
\hline pRD1 & Carries the $\mathrm{K} 4$ antigen gene cluster & Drake et al. (1990) \\
\hline pRD10 & Flanks the $\mathrm{K} 4$ antigen gene cluster & See text \\
\hline
\end{tabular}

*Addresses: $a$, ICI Pharmaceuticals, Macclesfield, UK; $b$, Max-Planck-Inst., Freiburg, Germany; $c$, Univ. Guelph, Canada; $d$, State Serum Inst., Copenhagen, Denmark.

1986, 1988a). Regions 1 and 3 are homologous between different group II capsule gene clusters and are thought to encode products that perform identical functions in the expression of chemically different group II capsules (Boulnois et al., 1987; Roberts et al., 1988 a; Boulnois \& Roberts, 1990). Region I is about $7 \mathrm{~kb}$ and, in part, encodes proteins for the transport of mature, phosphatidic-acid-linked polysaccharide from the periplasm to the cell surface. In addition, the structural gene encoding CKS is located within region 1 (C. Pazzani \& I. S. Roberts, unpublished results). The role of this enzyme is unclear, but since KDO has been found at the terminus of some group II capsular polysaccharides that do not have KDO in the repeat unit (Jann \& Jann, 1990) CKS has been postulated to play a part in the initiation of polymer biosynthesis (Finke et al., 1989). Region 3 is $1.6 \mathrm{~kb}$ and encodes two proteins believed to be involved in the translocation of group II polysaccharide across the inner membrane (Kroncke et al., 1990; Smith et al., 1990; Pavelka et al., 1991). Region 2 appears to be unique for each group II capsule gene cluster and is positioned between regions 1 and 3 (Boulnois \& Jann, 1990). The available evidence suggests that region 2 encodes enzymes for the synthesis of the group II polysaccharide in question (Boulnois et al., 1987; Roberts et al., 1988a). In the case of the K1 antigen gene cluster, region 2 encodes for the synthesis and activation of CMP-sialic acid, the sole precursor for the polymerization of the $\mathrm{K} 1$ polysaccharide (Vimr et al., 1989). An isolate expressing a given group II capsule carries region 2 determinants for the biosynthesis of that polysaccharide only and silent region 2 determinants are not present on the $E$. coli chromosome (Roberts et al., $1988 b)$.

The ser $A$-linked group II capsule genes were originally thought to encode a distinct group of capsules. However, recent biochemical evidence has shown that some capsules previously assigned as members of group II resemble those of group I on two counts. First, K3, K10, K11, K54 and K98 antigens are expressed at all growth temperatures (Ørskov et al., 1984). Second, the K2, K3, $\mathrm{K} 10, \mathrm{~K} 11, \mathrm{~K} 19$ and $\mathrm{K} 54$ antigen-expressing strains do not have the elevated CKS activity at $37^{\circ} \mathrm{C}$ typical of group II capsule-producing strains (Finke et al., 1990). In all other respects, these capsules have typical group II characteristics and the mapping of the K10 and K54 capsule genes near ser $A$ was originally used to define the chromosomal location of kpsA (Ørskov \& Nyman, 1974). However, in the light of this more recent evidence Finke et al. (1990) tentatively classed these former group II capsules as group I/II. The nature of the group I/II capsule genes and their relationship to the group II capsule genes is not clear.

In this paper we report a Southern blot analysis of group I, group I/II and group II capsule-expressing $E$. coli strains to determine the relationship between genes for the production of different capsular polysaccharides.

\section{Methods}

Bacterial strains and plasmids. The bacterial strains and plasmids used in this study are listed in Table 1 . Bacteria were grown in L-broth (with $1.5 \%$ agar as required). Plasmids were propagated in $E$. coli LE392 using L-broth supplemented with $100 \mu \mathrm{g}$ ampicillin (Ap) $\mathrm{ml}^{-1}$ 

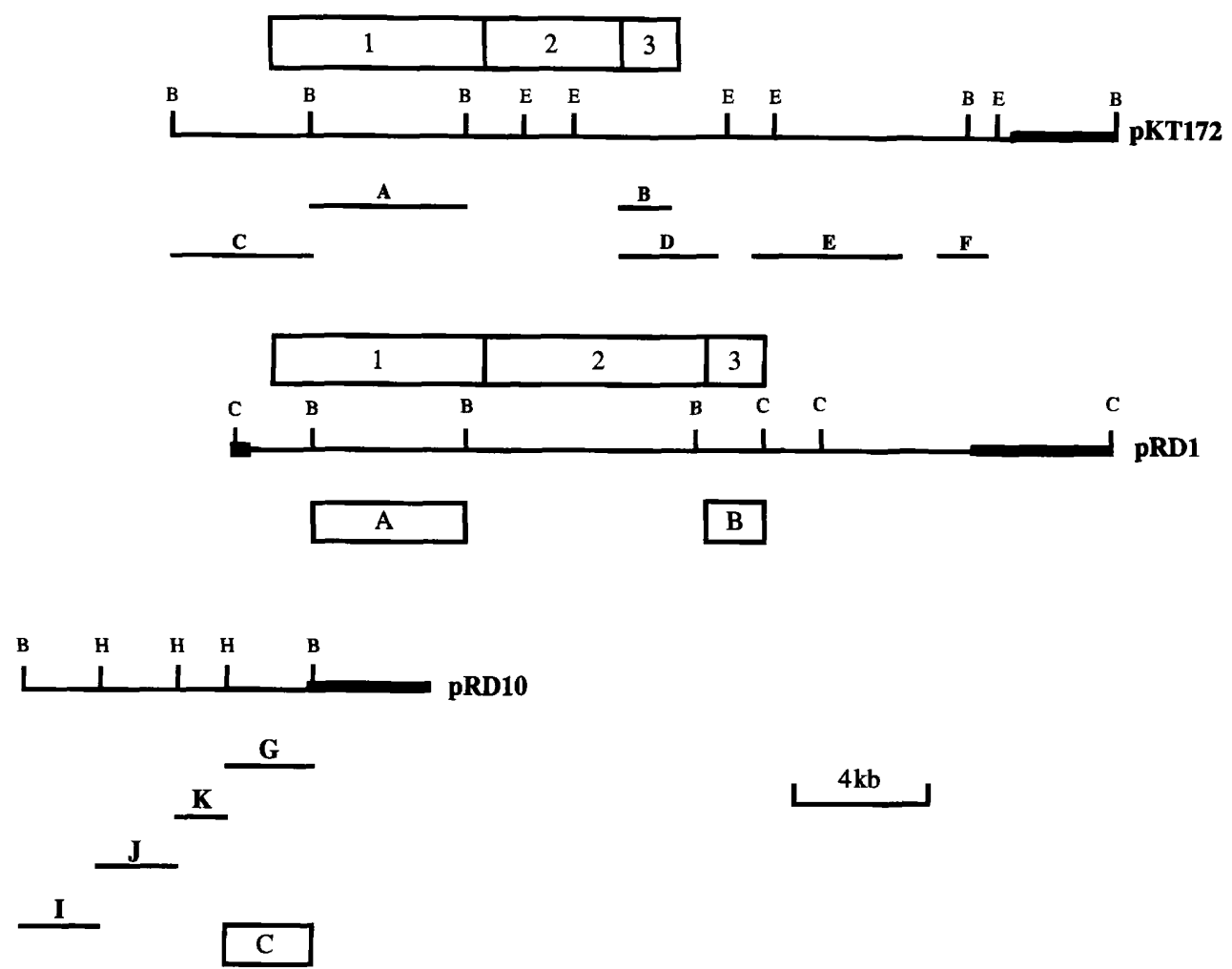

Fig. 1. Physical map of the recombinant plasmid pKT172 (carrying the biosynthesis genes for the K1 antigen), pRD1 (cloned K4 biosynthesis genes) and pRD10 (see text). The black bars refer to vector sequences. The labelled boxes 1 through 3 refer to functional gene blocks involved in the production of the $\mathrm{K} 1$ and $\mathrm{K} 4$ antigens (see text). The DNA probes are represented by the lines labelled A through $\mathrm{K}$. The lettered boxes denote regions of homology with the appropriate probe. Restriction enzyme target sites: B, BamHI; C, ClaI; E, EcoRI; H, HpaI.

or $25 \mu \mathrm{g}$ of either chloramphenicol $(\mathrm{Cm})$ or tetracycline $(\mathrm{Tc}) \mathrm{ml}^{-1}$ as needed.

DNA procedures. Chromosomal and plasmid DNA was extracted as described by Saito \& Miura (1963) and Birnboim \& Doly (1979), and cleaved with restriction endonucleases according to the manufacturer's recommendations. DNA fragments were separated by agarose gel electrophoresis, photographed and transferred to nylon filters (Hybond-N, Amersham) in preparation for DNA hybridization, as described by Southern (1975) and Sambrook et al. (1989). The conditions for DNA radiolabelling have been described by Feinberg $\&$ Vogelstein (1983). The hybridization solution used was $3 \times \mathrm{SSC}$ $(1 \times \mathrm{SSC}$ is $0.15 \mathrm{M}-\mathrm{NaCl}$ and $0.15 \mathrm{M}$-sodium citrate, $\mathrm{pH} 7.0)$ and $2 \times$ Denhardt's Solution [ $50 \times$ Denhardt's solution is $1 \%(\mathrm{w} / \mathrm{v})$ each of Ficoll, bovine serum albumin and polyvinylpyrollidone], $0 \cdot 1 \%$ SDS, $6 \%(\mathrm{v} / \mathrm{v})$ polyethylene glycol 6000 containing $200 \mu \mathrm{g}$ salmon sperm DNA ml-1. Hybridizations were performed at $65^{\circ} \mathrm{C}$ in duplicate and washed at $65^{\circ} \mathrm{C}$ in either $2 \times \mathrm{SSC}, 0.1 \%$ SDS or $0.5 \times \mathrm{SSC}, 0.1 \% \mathrm{SDS}$ allowing $30 \%$ or $15 \%$ mismatch respectively. Washing conditions requiring $95 \%$ similarity were $0.1 \times \mathrm{SSC}, 0.1 \% \mathrm{SDS}$ at $65^{\circ} \mathrm{C}$. Fragment sizes were calculated from multiple autoradiographs with reference to size markers on a gel photograph. All strains were checked by serotyping following experimentation.

\section{Results}

The K9, K29 and K30 antigens were chosen as representative of the group I capsules and the $\mathrm{K} 1, \mathrm{~K} 4$ and $\mathrm{K} 5$ antigens as typical group II capsules (Table 1).
The $\mathrm{K} 2$, K3, K10, $\mathrm{K} 11, \mathrm{~K} 19$ and $\mathrm{K} 54$ antigens are members of group I/II (Finke et al., 1990). Gene clusters for the $\mathrm{K} 1, \mathrm{~K} 4$ and $\mathrm{K} 5$ antigens have already been cloned and characterized (Echarti et al., 1983; Roberts et al., 1988a; Drake et al., 1990).

\section{Group I and I/II capsule-expressing E. coli strains lack group II capsule genes}

Southern blot analysis was used to determine whether strains which express a group I capsule also carry the group II capsule genes on the chromosome. Two radiolabelled DNA probes, A and B (Fig. 1) from the cloned $\mathrm{K} 1$ antigen gene cluster were used to probe chromosomal DNA from group I capsule-producing $E$. coli. Probe A carries the majority of the region 1 genes (Roberts et al., 1988b) and probe B carries the region 3 genes (Fig. 1). Both probes hybridized to group II chromosomal DNA fragments of the size predicted from the known restriction enzyme cleavage maps of the respective capsule gene clusters, yet failed to hybridize with the chromosomal DNA of all strains expressing a group I capsule. The results are summarized in Table 2 and those obtained with probe A illustrated in Fig. 2(a). 
Table 2. Summary of a series of Southern blot analyses of 11 different E. coli strains using radiolabelled DNA probes $A, B, D, E$ and $F$ (Fig. 1)

The $\mathrm{K}$ antigen expressed by each strain and the capsule group to which it belongs are listed. Chromosomal DNA from each strain was digested with the restriction endonuclease BamHI. The same results were achieved when the filters were washed at either high $(0.5 \times \mathrm{SSC}, 0.1 \%$ SDS at $\left.65^{\circ} \mathrm{C}\right)$ or low $(2 \times \mathrm{SSC}, 0.1 \%$ SDS $)$ stringency. The size of chromosomal DNA fragments homologous to each probe are listed in kilobases and a dash indicates that no fragments bound the probe, ND = not done.

\begin{tabular}{|c|c|c|c|c|c|c|c|c|c|c|c|}
\hline \multirow{2}{*}{$\begin{array}{r}\text { Group... } \\
\mathrm{K} \text { antigen... }\end{array}$} & \multicolumn{3}{|c|}{ I } & \multicolumn{3}{|c|}{ II } & \multicolumn{5}{|c|}{$\mathrm{I} / \mathrm{II}$} \\
\hline & K9 & K29 & K30 & K1 & K4 & K5 & $\mathbf{K} 2$ & $\mathrm{~K} 3$ & K10 & K11 & K19 \\
\hline Probe A & - & - & - & 5 & 5 & 5 & 5 & - & - & - & - \\
\hline Probe B & - & - & - & $>12$ & 8 & 12 & $>12$ & - & - & - & - \\
\hline Probe D & 8 & $>12$ & 8 & $>12$ & ND & ND & ND & 8 & $>12$ & 11 & ND \\
\hline Probe E & $>12$ & $>12$ & $>12$ & $>12$ & ND & ND & ND & $>12$ & 8 & - & ND \\
\hline Probe F & $>12$ & $>12$ & $>12$ & 3 & ND & ND & ND & $>12$ & 12 & - & ND \\
\hline
\end{tabular}

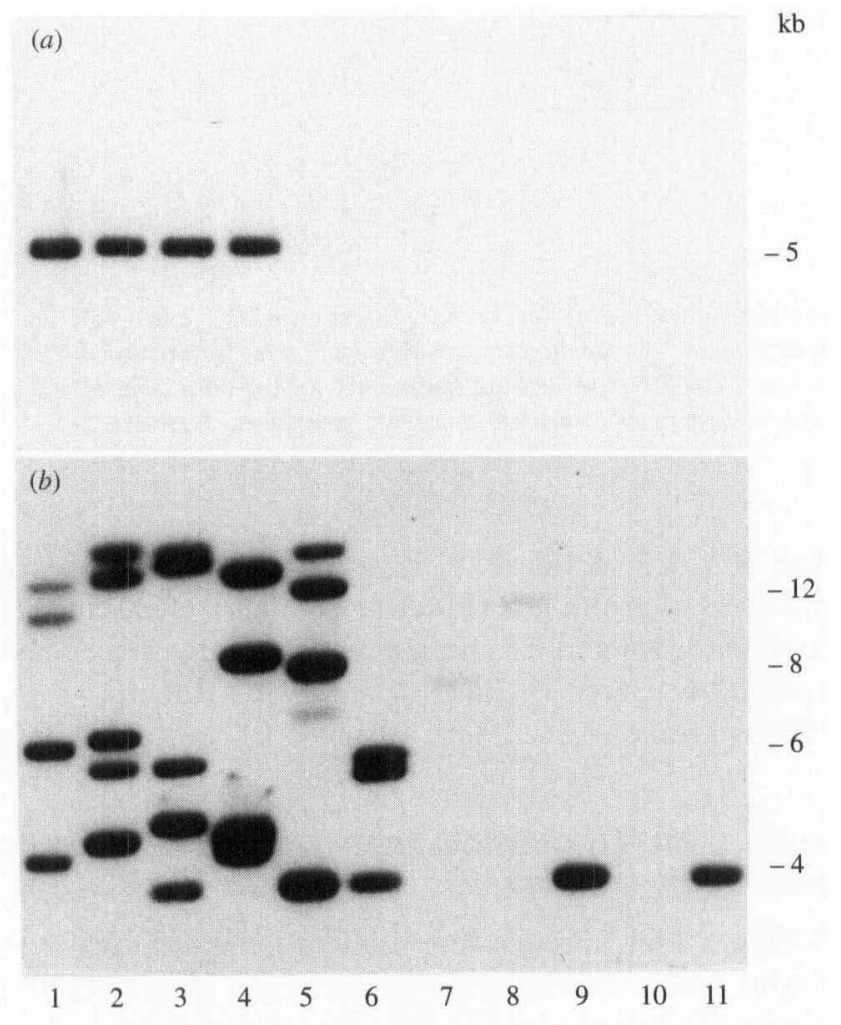

Fig. 2. Southern blot analysis using radiolabelled probes $A$ and $J$ (Fig. 1) of chromosomal DNA from 11 E. coli strains each expressing a different $\mathrm{K}$ antigen. (a) Chromosomal DNA digested with restriction endonuclease BamHI and hybridized with probe A. (b) Chromosomal DNA digested with $H p a I$ and hybridized with probe J. DNA was loaded as follows: Lane $1, \mathrm{~K} 1 ; 2, \mathrm{~K} 4 ; 3, \mathrm{~K} 5 ; 4, \mathrm{~K} 2 ; 5, \mathrm{~K} 3 ; 6, \mathrm{~K} 10$; 7 , $\mathrm{K} 11$; 8, K19; 9, K9; 10, K29; 11, K30. The filters shown were washed at high stringency $\left(0.5 \times \mathrm{SSC}, 0.1 \%\right.$ SDS at $\left.65^{\circ} \mathrm{C}\right)$. Prolonged autoradiography of filter (a) did not reveal additional bands.

Southern blot analysis with the same DNA probes was used to determine whether the group I/II capsuleencoding genes are similar to, or distinct from, the group
II capsule genes. Neither probe A nor probe B hybridized to the chromosomal DNA of K3, K10, K11, K19 (Fig. $2 a$ ) and K54 capsule-expressing strains (Table 2). However, both probes A and B did hybridize to genomic DNA of the $\mathrm{K} 2$ capsule-producing $E$. coli.

\section{Analysis of sequences flanking region 3 of the group II capsule genes}

It is apparent that the chromosome of group I and I/II capsule-expressing strains lack the group II capsule determinants. This chromosomal difference may not be restricted to the group II capsule genes but may also include the sequences either side of them. Plasmid pKT172 caries $17 \mathrm{~kb}$ of DNA not involved in capsule expression but adjacent to region 3 of the $\mathrm{K} 1$ capsule gene cluster (Echarti et al., 1983) and probes D, E and F (Fig. 1) span these sequences. First, to determine whether the sequences adjacent to region 3 in different group II capsule gene clusters are homologous, probes D, E and $F$ were used in Southern blot analysis of $\mathrm{pRD1}$ and pGB110, which encode the K4 and K5 capsule genes respectively. The filters were washed under conditions of high stringency requiring $95 \%$ sequence similarity for hybridization. Probes D, E and F hybridized to the DNA fragments in both plasmids which are predicted from the restriction endonuclease cleavage map to lie beyond region 3 of the capsule genes (data not shown). In similar experiments, probes $\mathrm{D}, \mathrm{E}$ and $\mathrm{F}$ hybridize to single fragments in the chromosomal DNA from the group I, group II and group I/II capsule-expressing strains, with the exception of the K11 capsule-expressing strain to which probes $\mathrm{E}$ and $\mathrm{F}$ failed to hybridize (Table 2). These experiments with probes $\mathrm{D}, \mathrm{E}$ and $\mathrm{F}$ indicate that the $\mathrm{K} 1$, $\mathrm{K} 4$ and $\mathrm{K} 5$ capsule gene clusters are at the similar chromosomal location and that unlike group II capsule genes, sequences adjacent to region 3 of the group II 
Table 3. Summary of a series of Southern blot analyses of chromosomal DNA of different encapsulated $E$. coli strains with various probes (Fig. 1)

Refer to the legend of Table 2 for details. Subscript $\mathrm{H}$ or B indicates that chromosomal DNA was cleaved with either $H p a I$ or BamHI respectively.

\begin{tabular}{|c|c|c|c|c|c|c|c|c|c|c|c|}
\hline \multirow{2}{*}{$\begin{array}{l}\text { Group... } \\
\text { K antigen ... }\end{array}$} & \multicolumn{3}{|c|}{ I } & \multicolumn{3}{|c|}{ II } & \multicolumn{5}{|c|}{ I/II } \\
\hline & K9 & K29 & $\mathrm{K} 30$ & K1 & K4 & K5 & $\mathrm{K} 2$ & K3 & K10 & $\mathrm{K} 11$ & K19 \\
\hline Probe C & - & - & - & 7 & $>12$ & $>12$ & 12 & - & - & - & - \\
\hline Probe $\mathrm{G}$ & - & - & - & 7 & $>12$ & $>12$ & 12 & - & - & - & - \\
\hline Probe $K_{B}$ & - & - & - & $\begin{array}{l}>12 \\
>12\end{array}$ & $\begin{array}{l}>12 \\
>12\end{array}$ & $\begin{array}{r}12 \\
8\end{array}$ & $\begin{array}{r}>12 \\
12\end{array}$ & $\begin{array}{r}>12 \\
>12 \\
10 \\
7\end{array}$ & $\begin{array}{l}>12 \\
>12\end{array}$ & $\begin{array}{r}12 \\
11\end{array}$ & $>12$ \\
\hline Probe $K_{H}$ & - & - & - & $\begin{array}{r}>12 \\
>12 \\
8\end{array}$ & $\begin{array}{l}3 \\
2 \cdot 5\end{array}$ & $>12$ & $>\begin{array}{r}12 \\
3\end{array}$ & $\begin{array}{r}>12 \\
7 \\
4 \\
2 \cdot 5\end{array}$ & $\begin{array}{l}2 \cdot 5 \\
2\end{array}$ & $\begin{array}{r}10 \\
3\end{array}$ & 12 \\
\hline Probe $\mathbf{J}_{\mathrm{B}}$ & $>12$ & - & $>12$ & $\begin{array}{l}>12 \\
>12\end{array}$ & $\begin{array}{l}>12 \\
>12\end{array}$ & $\begin{array}{r}>12 \\
>12 \\
9\end{array}$ & $\begin{array}{l}>12 \\
>12 \\
>12\end{array}$ & $\begin{array}{r}>12 \\
>12 \\
12 \\
8\end{array}$ & $\begin{array}{l}>12 \\
>12 \\
>12\end{array}$ & $>12$ & $>12$ \\
\hline Probe $\mathbf{J}_{\mathbf{H}}$ & $3 \cdot 5$ & - & $3 \cdot 5$ & $\begin{array}{l}12 \\
10 \\
5 \cdot 5 \\
3 \cdot 5\end{array}$ & $\begin{array}{r}>12 \\
12 \\
6 \\
5 \\
4\end{array}$ & $\begin{array}{r}>12 \\
>12 \\
5 \\
4.5 \\
\\
3.5\end{array}$ & $\begin{array}{r}12 \\
8 \\
4 \\
4\end{array}$ & $\begin{array}{r}>12 \\
11 \\
8 \\
7 \\
3 \cdot 5\end{array}$ & $\begin{array}{l}6 \cdot 5 \\
5 \cdot 5 \\
5 \\
3 \cdot 5\end{array}$ & 7 & 10 \\
\hline Probe $I_{B}$ & 4 & - & 4 & $\begin{array}{r}>12 \\
4\end{array}$ & $\begin{array}{l}>12 \\
>12\end{array}$ & $\begin{array}{r}>12 \\
>12 \\
12\end{array}$ & $\begin{array}{r}>12 \\
12 \\
8 \\
6 \\
4\end{array}$ & $\begin{array}{r}>12 \\
>12 \\
9 \\
8 \\
7 \\
4\end{array}$ & $\begin{array}{l}>12 \\
>12\end{array}$ & $\begin{array}{l}>12 \\
>12\end{array}$ & - \\
\hline Probe $I_{H}$ & $>12$ & - & $<12$ & $6 \cdot 5$ & $\begin{array}{c}>12 \\
12 \\
9 \\
6 \\
3 \cdot 5\end{array}$ & $\begin{array}{r}>12 \\
>12 \\
9 \\
6 \\
2\end{array}$ & $\begin{array}{r}>12 \\
>12 \\
9 \\
6.5 \\
5.5\end{array}$ & $\begin{array}{c}>12 \\
9 \\
6 \cdot 5 \\
3\end{array}$ & $\begin{array}{l}9 \\
6 \\
3\end{array}$ & 8 & - \\
\hline
\end{tabular}

capsule gene clusters may be present on the chromosome of most, but not all, $E$. coli isolates.

\section{Analysis of sequences flanking region 1 of the group II capsule genes}

Since DNA sequences flanking region 3 of the group II capsule genes are present in many $E$. coli isolates (see above), similar studies were performed to see whether this also applies to those sequences flanking region 1 of the group II capsule genes. Probe C (Fig. 1), which is $4 \mathrm{~kb}$ in length, extends from a BamHI site $1 \mathrm{~kb}$ within region 1 of the $\mathrm{K} 1$ gene cluster to a BamHI site fortuitously generated in the original cloning of the K1 genes in the construction of pKT172 (Echarti et al., 1983) (Fig. 1). This probe was used in Southern blot analysis of the genome of various encapsulated E. coli. Homologous sequences were only detected in those strains which carry the group II capsule genes (Table 3), as well as the K2 capsule-expressing strain. The equivalent probe taken from pRD10 (probe G, Fig. 1) gave identical results (Table 3). From this, we conclude that at least $3 \mathrm{~kb}$ of DNA adjacent to region 1 of the $\mathrm{K} 1$ and $\mathrm{K} 4$ antigen gene clusters is not present on the chromosome of strains which do not carry the group II capsule determinants, although there is no evidence to suggest that is essential or involved in group II capsule biogenesis.

To obtain probes extending beyond the sequences covered by probe $\mathrm{G}$, a previously constructed cosmid library of E. coli U1-41 (Drake et al., 1990) was screened by colony hybridization using probe $\mathrm{A}$. Ten recombinants were identified that carry sequences homologous to probe A (Fig. 1) yet failed to produce the K4 antigen (Drake et al., 1990). Plasmid DNA was extracted from each recombinant, cleaved with BamHI and subjected to Southern blot analysis using radiolabelled probe C. A $15.5 \mathrm{~kb}$ BamHI fragment of U1-41 genomic DNA, present within seven of the recombinants, 


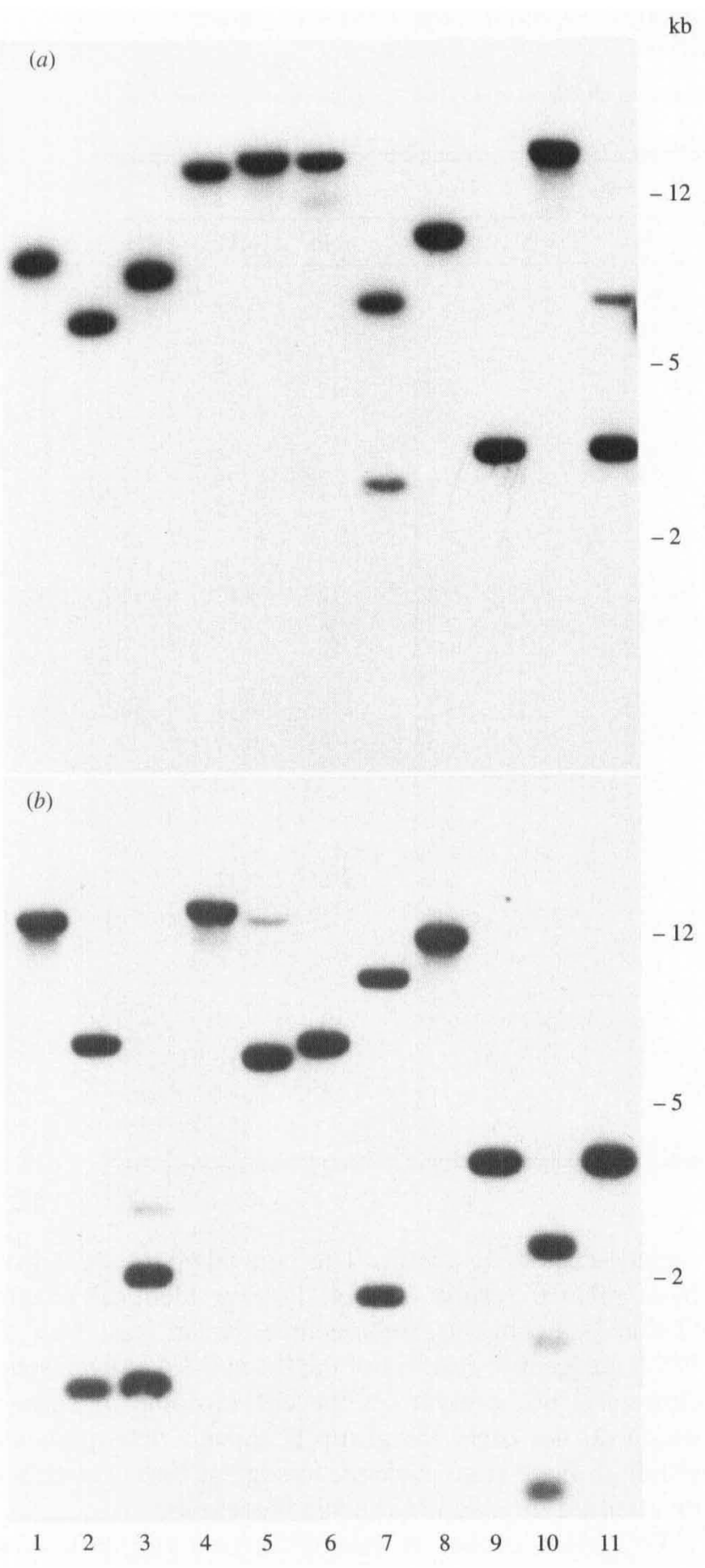

Fig. 3. Chromosomal DNA from $E$. coli K9 was cleaved with the restriction endonuclease indicated and subjected to Southern blot analysis. A single nylon filter was hybridized with $(a)$ probe $\mathrm{D}$ and then stripped and hybridized with (b) probe J. Lane 1, BamHI; 2, EcoRI; 3, PstI; 4, Hind III; 5, KpnI; 6, ClaI ; 7, PvuII; 8, DraI; 9, HincII; 10, EcoRV; 11, HpaI.

hybridized to probe $\mathrm{C}$ (data not shown). This fragment was subcloned from one recombinant using the vector pACYC184 to generate the plasmid pRD10. A restriction endonuclease cleavage map of pRD10 was constructed and the extent of homology with probe $C$ established by Southern blot analysis (Fig. 1).

Three DNA probes, $\mathrm{I}, \mathrm{J}$ and $\mathrm{K}$ taken from $\mathrm{pRD} 10$ (Fig. 1), were used in Southern blot analysis of HpaI- or BamHI-cleaved chromosomal DNA of the test strains. The results are summarized in Table 3 and those obtained with probe $\mathrm{J}$ illustrated in Fig. 2(b). In the case of group II and group I/II probes $\mathrm{I}, \mathrm{J}$ and $\mathrm{K}$ hybridized to multiple DNA fragments.

\section{Analysis of $\mathrm{K} 9$ chromosomal DNA}

Probes $\mathbf{J}$ and $\mathrm{D}$ represent the sequences closest to regions 1 and 3 respectively of the group II $\mathrm{K}$ antigen gene clusters that also both hybridize to group I capsuleexpressing strains (Tables 2 and 3 ). To determine whether probes $\mathrm{D}$ and $\mathrm{J}$ derive from contiguous sequences on the chromosome of group I capsule-expressing strains, chromosomal DNA from $E$. coli $\mathrm{K} 9$ was cleaved with a variety of restriction enzymes and used in Southern blot analysis with probes $\mathrm{D}$ and $\mathbf{J}$. A comparison of the pattern of hybridization of the two probes revealed that probes $\mathrm{D}$ and $\mathrm{J}$ always hybridized to different fragments, indicating that the sequences that flank the group II capsule genes are not contiguous on the $\mathrm{K} 9$ chromosome (Fig. 3).

\section{Discussion}

DNA probes taken from regions 1 and 3 of the cloned $\mathrm{K} 1$ antigen gene cluster (Fig. 1) detect highly homologous sequences in all group II capsule-producing $E$. coli so far tested (Roberts et al., 1988b). Sequences homologous to regions 1 and 3 were not detected in the chromosomal DNA of the group I capsule-producing strains, even at low stringency (Table 2 and Fig. $2 a$ ). Therefore, whilst the transport mechanisms encoded by regions 1 and 3 are capable of handling a diversity of group II polysaccharides ranging from the homopolymer $\mathrm{K} 1$ to the substituted heteropolymer K4 (Drake et al., 1990), the results of this study would suggest that group I capsule expression is independent of these mechanisms and that silent copies of the group II capsule genes are not present near ser $A$.

With the exception of the $\mathrm{K} 2$ strain, sequences homologous to the group II capsule gene cluster were not detected in group I/II capsule-expressing strains (Table 2 and Fig. $2 a$ ) even though both the group II (Ørskov et al., 1976) and group I/II capsule genes (Ørskov \& Nyman, 1974) have been mapped to the same locus and the capsules share many biochemical characteristics. The hybridization between probes A and B (Fig. 1) and chromosomal DNA from the K2 strain would suggest 
that K2 may be a group II capsule with aberrant temperature regulation and not a group I/II capsule as previously suggested by Finke et al. (1990). Hence, expression of group I/II capsules would appear not to utilize the group II capsule gene products, nor are these genes present on the chromosome. Studies of CMPKDO synthetase activity led Finke et al. (1990) to postulate the existence of a third group of $E$. coli capsular polysaccharides. The genetic information presented here supports the existence of a third group encoded by genes distinct from the group II capsule genes (at least as assessed by Southern blot analysis) but probably located at, or adjacent to, the same locus near ser $A$. Nevertheless, it is possible that these genes do encode for similar proteins that perform common steps in capsule biogenesis. Such a situation exists between the capsule gene clusters of Haemophilus influenzae, Neisseria meningitidis and E. coli group II. Despite a lack of nucleotide sequence homology these capsule gene clusters encode a number of functionally homologous proteins (Kroll et al., 1990; Frosch, et al., 1991). Therefore, further genetic analysis is necessary to determine the functional relationships between $E$. coli group II and group I/II capsule gene clusters.

DNA adjacent to region 3 of the group II genes hybridized to most strains regardless of capsule type (Table 2). Therefore, this DNA is a common component of the E. coli chromosome. This is consistent with the findings of Vimr (1991), in which the sequences adjacent to the $\mathrm{K} 1$ capsule genes were hybridized to the overlapping set of clones generated by Kohara et al. (1987). Since the K1 capsule genes were mapped to 64 minutes on the physical map of the $E$. coli chromosome (Vimr, 1991), it follows that the K4 and K5 capsule genes are also located at this site on the chromosome. This is likely to be true for all group II capsule gene clusters.

At least $3 \mathrm{~kb}$ of sequence immediately flanking region 1 of both the $\mathrm{K} 1$ and the $\mathrm{K} 4$ antigen clusters was present only on the chromosome of $E$. coli strains expressing group II capsule gene clusters as well as the K2 strain (Probe C, Fig. 1, Table 3). This further supports our hypothesis that the $\mathrm{K} 2$ strain may actually be a group II strain. This sequence, although only found in association with group II capsule genes, has not to date been implicated in capsule expression (Roberts et al., 1988a). A further $2.5 \mathrm{~kb}$ of DNA adjacent to this sequence (Probe K, Fig. 1, Table 3) is present on the chromosome only when group II or group I/II capsule genes are present. Beyond this DNA, sequences were present in most strains tested (Probes J and I, Fig. 1, Table 3). In a group I capsule-expressing strain (K9), although the group II capsule genes are absent, the flanking sequences that hybridize to probes $\mathrm{D}$ and $\mathrm{J}$ are not contiguous (Fig.
3). Thus, in this strain, DNA which is less than $70 \%$ homologous to the group II capsule genes must lie at this site.

A striking observation is that in many cases DNA flanking region 1 of the $\mathrm{K} 4$ capsule genes (probes $\mathrm{I}$, $\mathrm{J}$ and $\mathrm{K})$ hybridizes to multiple fragments in the chromosomal DNA from all the group II capsule-expressing isolates and two of the four group I/II strains studied (Fig. $2 b$ and Table 3). Given the sizes of the fragments that hybridize to these probes, it is unlikely that these repeated sequences are immediately adjacent to one another. Thus DNA flanking region 1 of the $\mathrm{K} 4$ capsule gene cluster is found in most $E$. coli regardless of capsule type and is repeated in group II and group I/II capsuleexpressing strains. The function(s) of the product(s) (if any) of this repeated DNA is unclear but it is thought not to play a role in group II capsule expression (Roberts et al., 1988a).

The evidence presented in this paper suggests that $E$. coli may have at least three distinct groups of gene clusters for the production of capsular polysaccharide, two of which appear to map to a locus near ser $A$. This ser $A$-linked locus is polymorphic and can adopt three allelic forms. Two of these alleles are associated with capsule expression (groups II and I/II), of which group II is known to be internally variable. The third form (group I) has no known association with capsule production. Comparison of the E. coli and Salmonella typhimurium linkage maps (Riley \& Krawiec, 1987) indicates that the $\operatorname{ser} A$ region of the chromosome of these organisms is one of a restricted number of sites at which acquisition of new genetic material has occurred. A predilection to acquire and perhaps reorganize genetic material at or adjacent to ser $A$ may be one mechanism for the generation of capsule diversity in $E$. coli and explain the polymorphic nature of this locus.

This work was supported by a SERC grant to I.S.R. and G.J.B. G. J. B. is a Lister Institute--Jenner Research Fellow. We are grateful to B. and K. Jann for providing strains and for useful discussion and to F. and I. Ørskov for both the provision of strains and the confirmation of serotype.

\section{References}

BiRnBorm, H. C. \& Doly, J. (1979). A rapid alkaline extraction procedure for screening recombinant plasmid DNA. Nucleic Acids Research 1, 1513-1523.

BoulnoIs, G. J., RoberTs, I. S., Hodge, R., HARdy, K. R., JANN, K. B. \& TIMmis, K. N. (1987). Analysis of the K1 capsule biosynthesis genes of Escherichia coli: definition of three functional regions for capsule production. Molecular and General Genetics 208, 242-246.

BoulNoIS, G. J. \& JANN, K. (1990). Bacterial polysaccharide capsule synthesis, export and evolution of diversity. Molecular Microbiology 3, 1819-1823.

Boulnois, G. J. \& RoberTs, I. S. (1990). Genetics of capsular polysaccharide production in bacteria. Current Topics in Microbiology and Immunology 150, 1-18.

Chang, A. C. Y. \& CohEN, S. N. (1978). Construction and 
characterization of amplifiable multicopy DNA cloning vehicles derived from the P15A cryptic miniplasmid. Journal of Bacteriology 134, 1141-1156.

Drake, C. R., Roberts, I. S., JanN, B., JanN, K. \& Boulnois, G. J. (1990). Molecular cloning and expression of the genes encoding the Escherichia coli $\mathrm{K} 4$ capsular polysaccharide, a fructose substituted chondroitin. FEMS Microbiology Letters 66, 227-230.

ECharti, C. E., Hirschel, B., Boulnois, G. J., VARLey, J. M., Waldvogel, F. \& Timmis, K. N. (1983). Cloning and analysis of the K1 capsule biosynthesis genes of Escherichia coli: lack of homology with Neisseria menigitidis group B DNA sequences. Infection and Immunity 41, 54-60.

Feinberg, A. P. \& Vogelstein, B. (1983). A technique for radiolabelling restriction endonuclease fragments to a high specific activity. Annals of Biochemistry 132, 6-13.

Finke, A., Roberts, I. S., Boulnois, G. J., Pazzani, C. \& Jann, K. (1989). Activity of CMP-KDO synthetase in Escherichia coli strains expressing the capsular K5 polysaccharide: implication for polysaccharide biosynthesis. Journal of Bacteriology 171, 3074-3075.

FINKE, A., JANN, B. \& JANN, K. (1990). CMP-KDO synthetase activity in Escherichia coli expressing different capsular polysaccharides. FEMS Microbiology Letters 69, 129-134.

Frosch, M., Edwards, U., Bousset, K., Krauße, B. \& Weisgerber, C. (1991). Evidence for a common molecular origin of the capsule gene loci in Gram-negative bacteria expressing group II capsular polysaccharides. Molecular Microbiology 5, 1251-1263.

JANN, K. (1985). Cell surface components and virulence: Escherichia coli $\mathrm{O}$ and $\mathrm{K}$ antigens in relation to virulence and pathogenicity. In The Virulence of Escherichia coli, pp. 156-176. Edited by $M$. Sussman. New York: Academic Press.

JANN, K. \& JANN, B. (1987). Polysaccharide antigens of Escherichia coli. Reviews of Infectious Diseases 9, 5517-5526.

JANN, B. \& JANN, K. (1990). Structure and biosynthesis of the capsular antigens of Escherichia coli. Current Topics in Microbiology and Immunology 150, 19-42.

JANN, K., DengleR, T. \& JANN, B. (1992). Core-lipid A on the K40 polysaccharide of Escherichia coli $08: \mathrm{K} 40: \mathrm{H} 9$, a representative of group I polysaccharides. Zentralblatt fur Bakteriologie 276, 196-204.

KoHARA, Y., AkiYama, K. \& Isono, K. (1987). The physical map of the whole Escherichia coli chromosome: application of a new strategy for rapid analysis and sorting of a large genomic library. Cell 50, 495-508.

Kroll, J. S., LoYnds, B., Brophy, L. \& Moxon, E. R. (1990). The bex locus in encapsulated Haemophilus influenzae: a chromosomal region involved in capsule polysaccharide export. Molecular Microbiology 4, 1853-1862.

Kroncke, K. D., Boulnois, G. J., Roberts, I. S., BitTer-Suerman, D., GoleckI, J., JANN, B. \& JANN, K. (1990). Expression of the Escherichia coli $\mathrm{K} 5$ capsular antigen: immunoelectron microscopic biochemical studies with recombinant DNA. Journal of Bacteriology 172, 1085-1091.

LaAsKo, D. M., Homonylo, M. K., Wilmot, S. J. \& Whitfield, C. (1988). Transfer and expression of the genetic determinants for $O$ and $\mathrm{K}$ antigen synthesis in Escherichia coli $\mathrm{O} 9: \mathrm{K}(\mathrm{A}) 30$ and Klebsiella sp. O1:K20 in E. coli K12. Canadian Journal of Microbiology 34, 987-992.

ØRSKOV, I. \& NYMAN, K. (1974). Genetic mapping of the antigenic determinants of two polysaccharide $K$ antigens, $K 10$ and $K 54$, in Escherichia coli. Journal of Bacteriology 120, 43-51.

ØrSkov, I., ShaRma, V. \& Ørskov, F. (1976). Genetic mapping of the $\mathrm{K} 1$ and K4 antigens (L) of Escherichia coli. Acta Pathologica et Microbiologica Scandinavica Section B 84, 125-131.

Ørskov, I., ØRSKov, F., JaNN, B. \& JaNN, K. (1977). Serology, chemistry and genetics of $\mathrm{O}$ and $\mathrm{K}$ antigens of Escherichia coli. Bacteriological Reviews 41, 667-710.

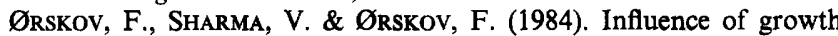
temperature on the development of Escherichia coli polysaccharide K antigens. Journal of General Microbiology 130, 2681-2684.

Pavelka, M. S., Wright, L. F. \& Silver, R. P. (1991). Identification of two genes, $k p s M$ and $k p s T$, in region 3 of the polysialic acid gene cluster of Escherichia coli K1. Journal of Bacteriology 173, 4603-4610.

RILEY, M. \& KRAWIEC, S. (1987). Genome organization. In Escherichia coli and Salmonella typhimurium: Cellular and Molecular Biology, pp. 967-981. Edited by F. C. Neidhardt and others. Washington DC: American Society for Microbiology.

Roberts, I. S., MOUNTFORd, R., High, N., BITTER-SuERMAN, D., JANN, K., Timmis, K. N. \& Boulnois, G. J. (1986). Molecular cloning and analysis of the genes for production of the $\mathrm{K} 5, \mathrm{~K} 7, \mathrm{~K} 12$ and $\mathrm{K} 92$ capsular polysaccharides of Escherichia coli. Journal of Bacteriology 168, 1228-1233.

Roberts, I. S., MountFord, R., Hodge, R., JANN, K. B. \& Boulnois, G. J. $(1988 a)$. Common organization of gene clusters for the production of different capsular polysaccharides ( $K$ antigens) in Escherichia coli. Journal of Bacteriology 170, 1305-1310.

ROBERTS, M., ROBERTS, I. S., KORHONEN, T. K., JANN, K., BitTERSuerman, D., Boulnois, G. J. \& Williams, P. H. (1988 $b$ ). DNA probes for $\mathrm{K}$ antigen (Capsule) typing of Escherichia coli. Journal of Clinical Microbiology 26, 385-387.

SAITo, H. \& MiURA, K. I. (1963). Preparation of transforming deoxyribonucleic acid by phenol treatment. Biochimica et Biophysica Acta 72, 619-629.

Sambrook, J., Fritsch, E. F. \& Maniatis, T. (1989). Molecular Cloning: a Laboratory Manual, 2nd edn. Cold Spring Harbor, NY Cold Spring Harbor Laboratory.

SCHMIDT, G., JANN, B. \& JANN, K. (1977). Genetic determinants of the synthesis of the polysaccharide capsular antigen K27(A) of Escherichia coli. Journal of General Microbiology 100, 355-361.

SCHMIDT, M. A. \& JANN, K. (1982). Phospholipid substitution of capsular (K) polysaccharide antigens from Escherichia coli causing extra-intestinal infections. FEMS Microbiology Letters 14, 69-74.

Silver, R. P., VANN, W. F. \& Aaronson, W. (1984). Genetic and molecular analysis of Escherichia coli $\mathrm{K} 1$ antigen gene. Journal of Bacteriology 157, 568-575.

SMITH, A. N., Boulnois, G. J. \& RoberTs, I. S. (1990). Molecular analysis of Escherichia coli $\mathrm{K} 5 \mathrm{kps}$ locus: identification and characterization of an inner membrane polysaccharide transport system. Molecular Microbiology 4, 1863-1869.

SOUTHERN, E. M. (1975). Detection of specific sequences among DNA fragments separated by gel electrophoresis. Journal of Molecular Biology 89, 503-517.

VIMR, E. R. (1991). Map position and genomic organization of the kps cluster for polysialic acid synthesis in Escherichia coli K1. Journal of Bacteriology 173, 1335-1338.

Vimr, E. R., Aaronson, W. \& Silver, R. P. (1989). Genetic analysis of chromosomal mutations in the polysialic gene cluster of $E$. coli $\mathrm{K} 1$. Journal of Bacteriology 171, 1106-1117. 